\title{
BMJ Open Vitamin D status and TB treatment outcomes in adult patients in Tanzania: a cohort study
}

\author{
Saurabh Mehta, ${ }^{1}$ Ferdinand M Mugusi, ${ }^{2}$ Ronald J Bosch, ${ }^{3}$ Said Aboud, ${ }^{4}$ \\ Willy Urassa, ${ }^{5}$ Eduardo Villamor, ${ }^{6}$ Wafaie W Fawzi ${ }^{7}$
}

To cite: Mehta S,

Mugusi FM, Bosch RJ, et al. Vitamin $D$ status and TB treatment outcomes in adult patients in Tanzania: a cohort study. BMJ Open 2013;3: e003703. doi:10.1136/ bmjopen-2013-003703

- Prepublication history and additional material for this paper is available online. To view these files please visit the journal online (http://dx.doi.org/10.1136/ bmjopen-2013-003703).

Received 1 August 2013 Revised 29 September 2013 Accepted 14 October 2013

CrossMark

For numbered affiliations see end of article.

Correspondence to Dr Saurabh Mehta; smehta@cornell.edu

\section{ABSTRACT}

Objectives: Vitamin $D$ is an immunomodulator and can alter response to tuberculosis (TB) treatment, though randomised trials have been inconclusive to date. We present one of the first comprehensive analysis of the associations between vitamin $D$ status and TB treatment, T-cell counts and nutritional outcomes by HIV status.

Design: Cohort study.

Setting: Outpatient clinics in Tanzania.

Participants: 25-hydroxyvitamin D levels were assessed in a cohort of 677 patients with TB (344 HIV infected) initiating anti-TB treatment at enrolment in a multivitamin supplementation (excluding vitamin D) trial (Clinicaltrials.gov identifier: NCT00197704).

\section{Primary and secondary outcome measures:}

Information on treatment outcomes such as failure and relapse, HIV disease progression, T-cell counts and anthropometry was collected routinely, with a median follow-up of 52 and 30 months for HIV-uninfected and HIV-infected patients, respectively. Cox and binomial regression, and generalised estimating equations were used to assess the association of vitamin D status with these outcomes.

Results: Mean 25-hydroxyvitamin $D$ concentrations at enrolment were $69.8( \pm 21.5) \mathrm{nmol} / \mathrm{L}(27.9( \pm 8.6) \mathrm{ng} /$ $\mathrm{mL}$ ). Vitamin $\mathrm{D}$ insufficiency $(<75 \mathrm{nmol} / \mathrm{L})$ was associated with a $66 \%$ higher risk of relapse $(95 \% \mathrm{Cl}$ $4 \%$ to $164 \% ; 133 \%$ higher risk in HIV-uninfected patients). Each unit higher 25-hydroxyvitamin $D$ levels at baseline were associated with a decrease of 3 $(p=0.004)$ CD8 and $3(p=0.01)$ CD3 T-cells/ $\mu L$ during follow-up in patients with HIV infection. Vitamin $D$ insufficiency was also associated with a greater decrease of body mass index (BMI; $-0.21 \mathrm{~kg} / \mathrm{m}^{2} ; 95 \%$ $\mathrm{Cl}-0.39$ to -0.02 ), during the first 8 months of follow-up. No association was observed for vitamin D status with mortality or HIV disease progression.

Conclusions: Adequate vitamin D status is associated with a lower risk of relapse and with improved nutritional indicators such as BMI in patients with TB, with or without HIV infection. Further research is needed to determine the optimal dose of vitamin $D$ and effectiveness of daily vitamin $D$ supplementation among patients with TB.

\section{Strengths and limitations of this study}

- The major strengths of this study include a large number of participants, more than half of whom were HIV-infected, comprehensive assessment of clinical, immunological, sociodemographic and nutritional parameters, and a long duration of follow-up.

- On the other hand, the major limitation is the possibility of reverse causation and residual confounding.

- We have attempted to minimise this through rigorous analyses and adjusting for several potential confounders, including haemoglobin concentrations, HIV status, viral load, CD4 T-cells and Karnofsky score, in most analyses.

\section{INTRODUCTION}

Mycobacterium tuberculosis is one of the most pernicious infectious diseases and successful pathogens known to man. More than $95 \%$ of the estimated cases and deaths due to tuberculosis (TB) occur in low-income countries. The United Republic of Tanzania is 1 of the 22 high-burden countries that account for $80 \%$ of global TB cases. Tanzania has an incidence of 177 cases/100 000 population/year and a prevalence of 183 cases $/ 100000 \mathrm{popu}-$ lation/year. ${ }^{1}$

The spread of HIV has fuelled the resurgence of the TB epidemic in Tanzania, as in other parts of sub-Saharan Africa. ${ }^{2}$ HIV is the strongest factor in the development of active $\mathrm{TB}$; it is estimated that only 1 of 10 immunocompetent persons infected with TB develops active TB in his/her lifetime; whereas, 1 of 10 HIV-infected persons infected with TB will develop active TB every year. An estimated $38 \%$ of patients with TB in Tanzania are also infected with HIV. ${ }^{1}$

Current treatment regimens, given under appropriate management conditions, are nearly $100 \%$ curative for patients with drugsusceptible organisms. However, in Tanzania, treatment fails in $12-17 \%$ of the cases. 
Additionally, patients with $\mathrm{TB}$ in settings such as Tanzania grapple with multiple health-related and quality-of-life issues, which are not addressed adequately with treatment alone.

Recent data have suggested that optimal vitamin D status may be associated with a more effective immune response to TB infection, a faster rate of bacteriological cure, and better long-term outcomes. For example, a recent cross-sectional study found that vitamin D deficiency is highly prevalent in South Africa and is associated with susceptibility to active $\mathrm{TB}$ both in the presence and absence of HIV infection. ${ }^{3}$ A few randomised trials have also been conducted; two of the recent ones failed to find an effect of vitamin D supplementation on treatment success. ${ }^{4}{ }^{5}$ However, the dose used and duration of supplementation may have precluded finding an effect. Further, most studies had small sample sizes and assessed only a limited number of covariates.

In this paper, we comprehensively examined the hypotheses that vitamin D status may be associated with response to treatment, risk of treatment failure, laboratory parameters such as T-cell counts and anthropometric measurements in the context of a randomised trial of micronutrient supplementation (supplement did not contain vitamin D) in Tanzania to better inform future studies or trials.

\section{MATERIALS AND METHODS \\ Study population}

The study population and recruitment methods have been described in detail earlier. ${ }^{6}$ Briefly, 887 adults with pulmonary tuberculosis (PTB) were enrolled in a randomised trial (Clinicaltrials.gov identifier: NCT00197704) to examine the effects of micronutrient supplementation on TB treatment failure, relapse and mortality. The trial started in April 2000 in Dar es Salaam, Tanzania and continued until April 2005. The eligibility criteria for the study included positive sputum smears for acid-fast bacilli (AFB), age between 18 and 65 years, Karnofsky performance score of $\geq 40 \%,{ }^{7}$ plan to stay in Dar es Salaam for 2 years, not being pregnant, and not having received anti-TB treatment during the previous 1 year. Consenting participants were randomly assigned in computergenerated permuted blocks of 20 , stratified by HIV status, to receive a daily oral dose of one of two regimens: micronutrients (5000 IU retinol, $20 \mathrm{mg}$ vitamin $\mathrm{B} 1,20 \mathrm{mg}$ vitamin $\mathrm{B} 2,25 \mathrm{mg}$ vitamin $\mathrm{B}_{6}, 100 \mathrm{mg}$ of niacin, $50 \mu \mathrm{g}$ vitamin $\mathrm{B}_{12}, 500 \mathrm{mg}$ vitamin $\mathrm{C}, 200 \mathrm{mg}$ vitamin $\mathrm{E}, 0.8 \mathrm{mg}$ folic acid and $100 \mu \mathrm{g}$ selenium) or placebo. These doses represent between 6 and 10 times the recommended dietary allowance (RDA) and were being tested at the time among HIV-infected adults from this setting. ${ }^{8}$ We chose multiples of the RDA because previous observational studies suggested that HIV-infected individuals need higher dietary intakes of micronutrients to achieve normal serum concentrations. ${ }^{9}$ All patients received a daily combination of rifampicin, isoniazid, pyrazinamide and ethambutol under direct observation of a health worker during the first 2 months (intensive phase) followed by 6 months of self-administered daily isoniazid and ethambutol, as per the Tanzania National TB and Leprosy Programme guidelines. None of the patients with HIV infection received antiretroviral therapy, as these medications were not routinely available in Tanzania at the time this trial was conducted.

At the time of randomisation, research nurses collected information on various sociodemographic characteristics including age, education levels, marital status and socioeconomic status. Anthropometric measurements were also obtained using standardised procedures ${ }^{10}$ at the randomisation visit as well as during each monthly follow-up visit. Height was measured to the nearest $0.1 \mathrm{~cm}$ using SECA Bodymeter 206 stadiometers, weight to the nearest $100 \mathrm{~g}$ with SECA 700 balance beam scales and left mid-upper arm circumference at the midpoint between the acromion and olecranon to the nearest $0.1 \mathrm{~cm}$ using non-stretchable tailor's tapes.

Physician visits were scheduled every 3 months. During these visits, study physicians inquired about the health of the participant during the preceding period and performed a complete physical examination. The stage of HIV disease was assessed according to the WHO system. $^{11}$

A written informed consent was obtained from all the study participants.

\section{Laboratory methods}

At the time of initiation of anti-TB treatment, HIV status was assessed among consenting patients using two sequential ELISAs (Wellcozyme, Murex Biotech; Enzygnost anti-HIV1/2 Plus, Dade Behring); discrepant results were resolved by western blot test (Bio-rad, Genetic Systems). Both pretest and post-test counselling was provided. A blood sample also was obtained for the measurement of haemoglobin and albumin concentrations using AcT Diff II haematology analyser (Beckman Coulter, Miami) and Hitachi 911 analyser (Roche Diagnostics), respectively. CD4, CD3 and CD8 T-cell counts were determined using FACScount or FACSCan systems (Becton Dickinson, California, USA). Viral load was also determined using the Amplicor HIV-1 monitor version 1.5 assay (Roche Molecular Systems, Branchburg, New Jersey, USA).

\section{Assessment of vitamin D status}

Serum 25-hydroxyvitamin D $(25(\mathrm{OH}) \mathrm{D})$ concentrations were measured using liquid chromatography-mass spectrometry at the Children's Hospital in Boston only at enrolment before the initiation of micronutrient supplementation. We defined vitamin $\mathrm{D}$ insufficiency status as serum $25(\mathrm{OH}) \mathrm{D}$ levels of less than $75 \mathrm{nmol} / \mathrm{L}$ and adequate otherwise. Vitamin $\mathrm{D}$ deficiency was defined as serum $25(\mathrm{OH}) \mathrm{D}$ levels of less than $50 \mathrm{nmol} / \mathrm{L}$. 


\section{Statistical analysis}

We examined the association of vitamin D status with $\mathrm{TB}$ treatment outcomes as well as nutritional, immunological and clinical end points in the entire cohort and separately by HIV status at baseline. TB-related endpoints included treatment failure, early relapse and late relapse. Treatment failure by 1 month was defined as positive AFB cultures at 1 month from the initiation of treatment. Relapses were deemed to have occurred in patients with positive cultures, among those who had become culture negative after treatment initiation. Relapses/recurrences included both endogenous reactivation and exogenous reinfection, which could not be distinguished in this study. We calculated the relative risks (RRs) and 95\% CIs for each of these outcomes by vitamin D status using binomial regression. We used Cox proportional hazards models to assess the association of vitamin D status with mortality in all patients and HIV disease progression from stage 3 to 4 in participants with HIV infection. We defined the end of follow-up as the date when HIV stage was last assessed.

We examined the association of vitamin $\mathrm{D}$ status with CD4, CD8 and CD3 T-cell counts, viral load (in participants with HIV infection), indicators of nutritional status (body mass index (BMI) and albumin concentrations) and haemoglobin concentrations using generalised estimating equations. These models do not require that all patients have the same number of follow-up assessments or that the follow-up measurements be obtained at exactly the same time points. We assumed a standard normal distribution for repeated continuous endpoints (T-cell subsets, $\log _{10}$ viral load, anthropometry and albumin and haemoglobin concentrations) and estimated average differences during follow-up by vitamin $\mathrm{D}$ status. We used an exchangeable correlation structure to account for withinparticipant correlations and adjusted the models for the follow-up time when the measurements had been obtained and for the baseline values.

We analysed the data for the entire period and for the first 8 months, coinciding with the expected end of TB treatment. Multivariate analyses adjusted for age, Karnofsky score, baseline haemoglobin concentrations, viral load, HIV status, CD4 T-cell counts and micronutrient supplementation, unless otherwise specified in the results section or the tables. All analyses were performed using SAS software V.9.3 (SAS Institute Inc, Cary, North Carolina, USA).

\section{RESULTS}

Baseline 25( $\mathrm{OH}) \mathrm{D}$ concentrations were available for 677 patients of the original cohort of 887 . Mean $25(\mathrm{OH}) \mathrm{D}$ concentration was $69.8( \pm 21.5) \mathrm{nmol} / \mathrm{L}(27.9( \pm 8.6) \mathrm{ng} /$ $\mathrm{mL}$ ) and its distribution is shown in figure 1 . The baseline characteristics of these 677 patients by HIV status are presented in table 1 . Thirty-six per cent of the patients with HIV infection had CD4 T-cell counts below

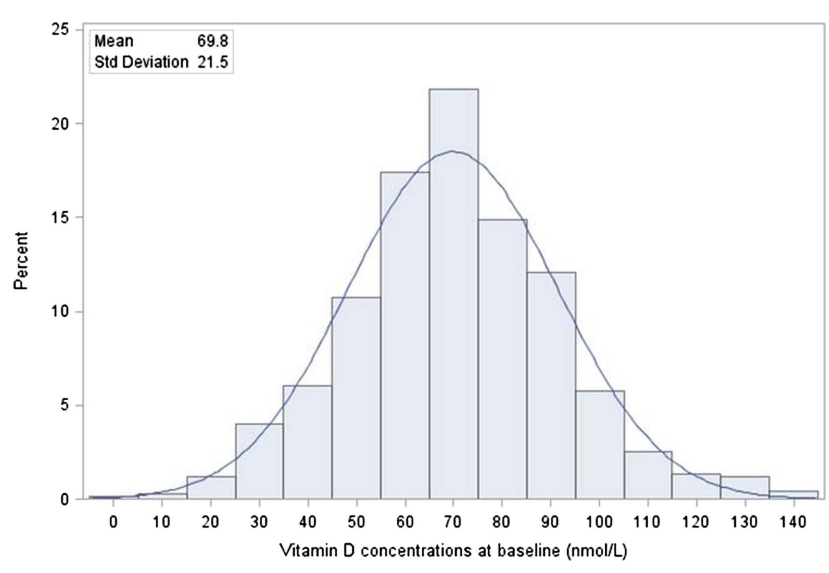

Figure 1 Distribution of 25-hydroxyvitamin D concentrations at baseline (nmol/L).

200 cells $/ \mu \mathrm{L}$. The mean BMI was $19.1 \pm 2.7 \mathrm{~kg} / \mathrm{m}^{2}$. The median follow-up time for patients with without HIV infection was 52 months (IQR: $47-57$ months) and for patients with HIV infection was 30 months (IQR: 1541 months).

The mean 25(OH)D concentrations were significantly different across season of blood draw in this cohort $(p=0.004)$. Tanzania has four seasons: dry (JanuaryFebruary); long rains (March-June); dry (JulyOctober); short rains (November-December). The boxplot of vitamin D's association with season of blood draw is presented in figure 2. In subgroup analyses, this association was only observed among patients without HIV infection.

We examined the correlates of vitamin D insufficiency, defined as serum $25(\mathrm{OH}) \mathrm{D}$ concentrations below $75 \mathrm{nmol} / \mathrm{L}(75 \mathrm{nmol} / \mathrm{L})$ in online supplementary tables S1 (HIV-uninfected) and 2 (HIV-infected). All factors that had univariate associations with $\mathrm{p}<0.20$ were included in a multivariate model; only the factors that had $p<0.05$ were retained in the final model. Among the HIV-uninfected subset, patients enrolled in the dry winter season between July and October were $50 \%$ more likely to have vitamin D insufficiency, compared with patients enroled in the dry summer season between January and February ( $p$ value for season=0.002). Similarly, the participants with the lowest height were more likely to have vitamin $D$ insufficiency $(p=0.01)$. Finally, greater expenditure on food per person per day was associated with a lower risk of having inadequate vitamin D status (RR/1000 Tanzanian Shillings (approximately 1 US $\$$ at the time of the study): $0.76 ; 95 \%$ CI 0.59 to 0.98$)$. In the HIV-infected subset, patients with higher haemoglobin concentrations at baseline were less likely to have vitamin D insufficiency, with a $7 \%$ lower risk per $1 \mathrm{~g} / \mathrm{dL}$ higher haemoglobin level $(\mathrm{p}=0.007)$. On the other hand, higher number of CD4 T-cells was associated with a higher risk of having inadequate vitamin $\mathrm{D}$ status $(4 \%$ higher risk per $100 \mathrm{CD} 4 \mathrm{~T}$ cells $/ \mu \mathrm{L} ; \mathrm{p}=0.02$ ). 
Table 1 Baseline characteristics of the study population $(n=677)$

\begin{tabular}{|c|c|c|}
\hline Variable & $\begin{array}{l}\text { HIV-infected }(n=344) \\
\text { Mean (SD) }\end{array}$ & $\begin{array}{l}\text { HIV-uninfected }(\mathrm{n}=333) \\
\text { Mean }(\mathrm{SD})\end{array}$ \\
\hline Age, years & $34.4 \pm 8.6$ & $30.2 \pm 9.2$ \\
\hline Money spent on food per person per day, Tanzanian Shillings* & $587.3 \pm 445.9$ & $580.1 \pm 684.2$ \\
\hline Haemoglobin, g/dL & $9.9 \pm 1.8$ & $11.1 \pm 1.7$ \\
\hline Albumin, $\mathrm{g} / \mathrm{dL}$ & $2.8 \pm 1.0$ & $3.2 \pm 1.1$ \\
\hline CD3 T-cell count, cells $/ \mu \mathrm{L}$ & $1228.0 \pm 608.5$ & $1195.9 \pm 404.8$ \\
\hline CD4 T-cell counts, cells/ $\mu \mathrm{L}$ & $327.2 \pm 246.2$ & $709.2 \pm 250.8$ \\
\hline CD8 T-cell counts, cells/ $\mu \mathrm{L}$ & $826.9 \pm 447.5$ & $427.5 \pm 188.2$ \\
\hline Log(10) viral load, copies/mL & $4.6 \pm 1.0$ & N/A \\
\hline Body mass index (BMl), $\mathrm{kg} / \mathrm{m}^{2}$ & $19.4 \pm 2.8$ & $18.8 \pm 2.5$ \\
\hline Mid-upper arm circumference, $\mathrm{cm}$ & $23.4 \pm 2.7$ & $23.1 \pm 2.7$ \\
\hline Follow-up time, days & $\begin{array}{l}916.8 \pm 507.4 \\
\mathrm{n}(\%)\end{array}$ & $\begin{array}{l}1532.9 \pm 331.4 \\
n(\%)\end{array}$ \\
\hline Vitamin D insufficiency (serum 25-hydroxyvitamin $D<75 \mathrm{nmol} / \mathrm{L}$ ) & $218(63.4)$ & $200(60.1)$ \\
\hline Vitamin D deficiency (serum 25-hydroxyvitamin D <50 nmol/L) & $55(16.0)$ & $51(15.3)$ \\
\hline \multicolumn{3}{|l|}{ Sex } \\
\hline Male & $203(59.0)$ & $257(77.2)$ \\
\hline Female & $141(41.0)$ & $76(22.8)$ \\
\hline \multicolumn{3}{|l|}{ Centre } \\
\hline Mwananyamala & $79(23.0)$ & $88(26.4)$ \\
\hline Temeke & $102(29.7)$ & $83(24.9)$ \\
\hline Tandale & $83(24.1)$ & $91(27.3)$ \\
\hline Mbgala & $31(9.0)$ & $70(21.0)$ \\
\hline Amana & $49(14.2)$ & $1(0.3)$ \\
\hline Karnofsky score $<70 \%$ & $45(13.1)$ & $29(8.7)$ \\
\hline \multicolumn{3}{|l|}{ Education group } \\
\hline None & $29(8.4)$ & $36(10.8)$ \\
\hline Low $<5$ years & $35(10.2)$ & $31(9.3)$ \\
\hline Primary $5-8$ years & $238(69.2)$ & $233(70.0)$ \\
\hline Secondary/university & $42(12.2)$ & $33(9.9)$ \\
\hline Cohabits with a partner & $200(58.1)$ & $168(50.5)$ \\
\hline \multicolumn{3}{|l|}{ Assets at home } \\
\hline None & 92 (26.9) & $108(32.4)$ \\
\hline 1 & $89(26.0)$ & $85(25.5)$ \\
\hline $2-3$ & $122(35.7)$ & $114(34.2)$ \\
\hline $4-5$ & $39(11.4)$ & $26(7.8)$ \\
\hline \multicolumn{3}{|l|}{ WHO HIV disease stage } \\
\hline 3 & $240(90.9)$ & $\mathrm{N} / \mathrm{A}$ \\
\hline 4 & $24(9.1)$ & \\
\hline \multicolumn{3}{|l|}{ CD4 T-cell categories, cells/ $\mu \mathrm{L}$} \\
\hline $0-199$ & 97 (35.9) & $0(0)$ \\
\hline 200-499 & $116(43.0)$ & 69 (22.9) \\
\hline $500+$ & $57(21.1)$ & $232(77.1)$ \\
\hline \multicolumn{3}{|l|}{ WHO BMI group, $\mathrm{kg} / \mathrm{m}^{2}$} \\
\hline$<16$ & $26(7.7)$ & $33(9.9)$ \\
\hline $16-16.99$ & 37 (10.9) & $45(13.6)$ \\
\hline $17-18.49$ & $73(21.5)$ & $88(26.5)$ \\
\hline $18.5-19.99$ & 79 (23.3) & $70(21.1)$ \\
\hline 20-21.99 & 77 (22.7) & $69(20.8)$ \\
\hline $22+$ & 47 (13.9) & $27(8.1)$ \\
\hline
\end{tabular}

There was no significant association of vitamin D status at TB treatment initiation with mortality or HIV disease progression in this cohort (table 2 includes only participants with HIV infection as there were only 13 deaths in the HIV-uninfected subset). There was no association observed between vitamin $\mathrm{D}$ status and treatment failure 1 month after initiation of TB treatment (table 3). However, patients with vitamin D insufficiency $(<75 \mathrm{nmol} / \mathrm{L})$ had a $66 \%$ higher risk of relapse after becoming culture-negative at 1 month after initiation of TB treatment $(95 \%$ CI $4 \%$ to $164 \%)$. This association was more pronounced in those who were not HIV 


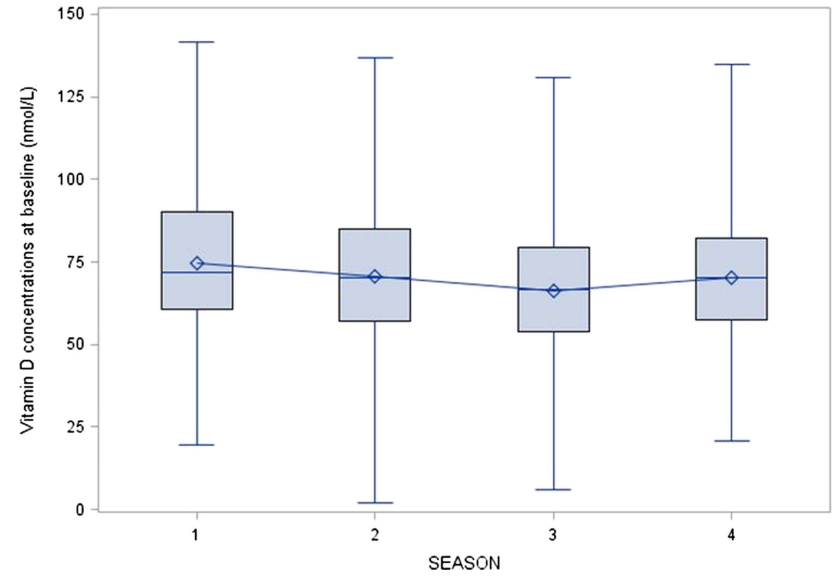

Figure 2 Distribution of 25-hydroxyvitamin D concentrations by season of blood draw; season 1: dry (January-February); season 2: long rains (March-June); season 3: dry (JulyOctober); season 4: short rains (November-December).

infected at enrolment in the study (RR: $2.33 ; 95 \%$ CI 1.26 to 4.29$)$. In analysis with continuous vitamin D levels, each $\mathrm{nmol} / \mathrm{L}$ increase was associated with a $1 \%$ lower risk of relapse during follow-up $(p=0.04)$.

Vitamin D insufficiency was observed to have no association with $\mathrm{CD} 4 \mathrm{~T}$-cell counts during the entire follow-up in either the HIV-infected or the HIV-uninfected subsets (table 4). However, vitamin D insufficiency was associated with greater CD4 T-cell counts during the first 8 months of follow-up in the patients with HIV infection (mean difference: 58; $95 \%$ CI 13 to 104).

In analysis among patients with HIV infection with continuous vitamin $\mathrm{D}$ levels, each nmol/L higher vitamin $\mathrm{D}$ concentration was associated with a decrease of three CD8 and three CD3 T-cells per $\mu \mathrm{L}$. Vitamin D insufficiency was associated with an average of 85 higher
CD8 T-cells/ $\mu \mathrm{L}$ during follow-up (95\% CI 4 to 165). Similar results were observed when we restricted the analyses to the first 8 months of follow-up: the duration of TB treatment at the time of the study in Tanzania. No relationship was observed with mean viral loads during follow-up in the patients who were HIV infected at the time of enrolment.

In analysis examining association of vitamin $\mathrm{D}$ status with nutritional parameters in the entire period of follow-up, no significant relationship was observed with BMI, albumin or haemoglobin concentrations (table 5). During the first 8 months of follow-up, patients with vitamin $\mathrm{D}$ insufficiency experienced a decline in BMI (mean: $-0.21 \mathrm{~kg} / \mathrm{m}^{2} ; 95 \%$ CI -0.39 to -0.02 ), compared with patients with adequate vitamin $\mathrm{D}$ status. These results were more pronounced in patients without HIV infection (mean $-0.34 ; 95 \%$ CI -0.60 to -0.09 ) and not significant in patients with HIV infection. Patients with HIV infection with vitamin D insufficiency had increased albumin levels (mean 0.94; 95\% CI 0.55 to 1.32) during the first 8 months of follow-up compared with patients with adequate vitamin $\mathrm{D}$ status.

\section{DISCUSSION}

In this study among 677 patients with TB in Tanzania, more than $61 \%$ of the participants had $25(\mathrm{OH}) \mathrm{D}$ concentrations below $75 \mathrm{nmol} / \mathrm{L}(30 \mathrm{ng} / \mathrm{mL}) .25(\mathrm{OH}) \mathrm{D}$ concentrations were associated with the season of blood draw, money spent on food per person per day, and height in HIV-uninfected participants and haemoglobin concentrations and CD4 T-cell counts among patients with HIV infection. Vitamin D insufficiency $(<75 \mathrm{nmol} /$ L) was not associated with mortality, HIV disease progression or treatment failure during follow-up in the entire cohort. However, patients with vitamin D insufficiency had an increased risk of experiencing TB relapse

Table 2 Vitamin D status and mortality and HIV disease progression in patients with HIV infection and tuberculosis

\begin{tabular}{|c|c|c|c|c|c|}
\hline \multirow[b]{2}{*}{ Outcome } & \multirow[b]{2}{*}{$\mathrm{n} / \mathrm{N}(\%)$} & \multicolumn{2}{|l|}{ Univariate } & \multicolumn{2}{|l|}{ Multivariate } \\
\hline & & IRR (95\% CI) & p Value & IRR (95\% CI) & p Value \\
\hline \multicolumn{6}{|l|}{ Mortality } \\
\hline Vitamin D insufficiency ( $<75 \mathrm{nmol} / \mathrm{L})$ & $61 / 218(28.0)$ & $0.73(0.50$ to 1.08$)$ & 0.12 & 0.70 (0.47 to 1.04$)$ & 0.08 \\
\hline Adequate vitamin D & $43 / 126(34.1)$ & & & & \\
\hline Vitamin D deficient (<50 nmol/L) & $20 / 55(36.4)$ & $1.34(0.82$ to 2.18$)$ & 0.25 & $0.91(0.551 .50)$ & 0.71 \\
\hline Not deficient & $84 / 289(29.1)$ & & & & \\
\hline Continuous vitamin $\mathrm{D}$ (nmol/L) & & $1.00(0.99$ to 1.01$)$ & 0.49 & 1.01 (1.00 to 1.02$)$ & 0.15 \\
\hline \multicolumn{6}{|l|}{ HIV disease progression } \\
\hline Vitamin D insufficiency ( $<75 \mathrm{nmol} / \mathrm{L})$ & $46 / 150(30.7)$ & $1.10(0.67$ to 1.82$)$ & 0.71 & 1.08 (0.64 to 1.82$)$ & 0.78 \\
\hline Adequate vitamin $\mathrm{D}$ & 23/90 (25.6) & Reference & & Reference & \\
\hline Vitamin D deficient (<50 nmol/L) & $14 / 34(41.2)$ & 1.91 (1.05 to 3.44$)$ & 0.03 & 1.48 (0.78 to 2.82$)$ & 0.23 \\
\hline Not deficient & $55 / 206(26.7)$ & Reference & & Reference & \\
\hline Continuous vitamin D (nmol/L) & & $0.99(0.98$ to 1.01$)$ & 0.30 & 1. $00(0.99$ to 1.01$)$ & 0.57 \\
\hline
\end{tabular}


Table 3 Vitamin D status and treatment outcomes in patients with tuberculosis

\begin{tabular}{|c|c|c|c|c|c|}
\hline \multirow[b]{2}{*}{ Outcome } & \multirow[b]{2}{*}{$\mathrm{n} / \mathrm{N}(\%)$} & \multicolumn{2}{|l|}{ Univariate } & \multicolumn{2}{|l|}{ Multivariate } \\
\hline & & $\overline{R R}(95 \% \mathrm{Cl})$ & p Value & $\overline{R R}(95 \% \mathrm{Cl})$ & p Value \\
\hline \multicolumn{6}{|c|}{ Treatment failure by 1 -month post-treatment initiation } \\
\hline Vitamin D insufficiency (<75 nmol/L) & $58 / 298(19.5)$ & $1.06(0.72$ to 1.55$)$ & 0.77 & $1.02(0.70$ to 1.49$)$ & 0.93 \\
\hline Adequate vitamin $\mathrm{D}$ & $34 / 185(18.4)$ & & & & \\
\hline Vitamin D deficient $(<50 \mathrm{nmol} / \mathrm{L})$ & $15 / 75(20.0)$ & $1.06(0.65$ to 1.74$)$ & 0.82 & $1.13(0.69$ to 1.86$)$ & 0.63 \\
\hline Not deficient & $77 / 408$ (18.9) & & & & \\
\hline Continuous vitamin D (nmol/L) & & $1.00(0.99$ to 1.01$)$ & 0.49 & 1. 00 (0.99 to 1.01$)$ & 0.50 \\
\hline \multicolumn{6}{|c|}{ Any relapse (relapse after 1 -month post-treatment initiation if culture negative at 1 month) } \\
\hline Vitamin D insufficiency (<75 nmol/L) & $51 / 227(22.5)$ & $1.56(0.98$ to 2.48$)$ & 0.06 & 1.66 (1.04 to 2.64$)$ & 0.03 \\
\hline Adequate vitamin $\mathrm{D}$ & $21 / 146(14.4)$ & & & & \\
\hline Vitamin D deficient $(<50 \mathrm{nmol} / \mathrm{L})$ & $13 / 56(23.2)$ & 1.25 (0.73 to 2.12$)$ & 0.41 & $1.40(0.82$ to 2.39$)$ & 0.21 \\
\hline Not deficient & $59 / 317(18.6)$ & & & & \\
\hline Continuous vitamin D (nmol/L) & & $0.99(0.98$ to 1.00$)$ & 0.06 & $0.99(0.98$ to 1.00$)$ & 0.04 \\
\hline
\end{tabular}

during follow-up. Further, vitamin D insufficiency was associated with a decline in CD8 and CD3 T-cells in both the first 8 months (the duration of TB treatment) and the entire period of follow-up. A similar relationship was observed with $\mathrm{BMI}$ in the first 8 months of follow-up.

Our study was conducted in Dar es Salaam, the largest urban centre in Tanzania, and just six degrees south of the Equator. The prevalence of vitamin D insufficiency $(>61 \%)$ in this study is higher than the approximately $40 \%$ found in a previous study among patients with TB in Mwanza, Tanzania ${ }^{12}$ and in our studies among HIV-infected pregnant women ( $\sim 85 \%$ of them had stage 1 HIV disease, unlike this study) in Dar es Salaam. ${ }^{13} 14$ However, this prevalence is lower than what was observed in a cross-sectional study in South Africa, where $88 \%$ of HIV-uninfected and $97 \%$ of HIV-infected patients with TB had vitamin $\mathrm{D}$ insufficiency. The mean vitamin $\mathrm{D}$ concentration in this study was $69.8 \mathrm{nmol} / \mathrm{L}$, compared with $86.5 \mathrm{nmol} / \mathrm{L}$ in the study in Mwanza and 28.8-40 nmol/L in the South African study. One study from Thailand observed similar levels $(69 \mathrm{nmol} / \mathrm{L})$ in patients with $\mathrm{TB} ;{ }^{15}$ Thailand is located at a similar distance from the Equator as Tanzania, though it is in the northern hemisphere. Similar to the study in South Africa, the vitamin D levels were lowest in our study in the dry winter season between July and October, though the differences were not as stark. For example, the mean vitamin D concentration in January-March in the South African study was 56.8 and $30.8 \mathrm{nmol} / \mathrm{L}$ between July and September, whereas in our study, the concentrations were $74.8 \mathrm{nmol} / \mathrm{L}$ for January through February, and $66.3 \mathrm{nmol} / \mathrm{L}$ for July through October.

Vitamin D is synthesised in the skin through the action of ultraviolet light on 7-dehydrocholesterol. Fatty fish, such as salmon and sardines, are good sources of vitamin $\mathrm{D}$ in the diet but are not widely available everywhere and are usually expensive. Increasing urbanisation and a tendency to spend most time indoors are major factors that contribute to the inability of the skin to synthesise adequate amounts of vitamin D. ${ }^{16-18}$ Additionally, the TB disease itself and/or the HIV co-infection in the participants in this study are probably the primary reasons for restricted physical activity, lack of adequate exposure to sunlight and consequent low concentrations of vitamin $\mathrm{D}$.

Several other investigators have examined correlates of vitamin $\mathrm{D}$ status in patients with TB. The study in Mwanza found that marital status, BMI and serum transferrin receptor concentrations were correlated with vitamin D status. Though the first two were correlated with vitamin D status in our study in univariate analyses, neither remained significant in multivariate analyses. We did not measure serum transferrin receptor in our study, though we did observe a correlation of vitamin D status with haemoglobin concentrations among the HIV-infected subset. Another study in South Africa found that TB status (active disease vs latent infection), month of sampling and BMI were significantly correlated with vitamin D status in multivariate analyses. ${ }^{3}$ All patients in our study had active disease, and we did not observe a relationship with BMI in our analyses. The study in South Africa incorporated only those correlates associated with serum $25(\mathrm{OH}) \mathrm{D}$ concentration with $\mathrm{p}<0.05$ in univariate analysis in the multivariate model. This may have precluded selection of important covariates and confounders, if measured, and produced biased estimates and CIs; increasing the nominal significance level to $20 \%$ or more, as used in this study ${ }^{19}$ can eliminate most of this bias. Most other studies have been with smaller sample sizes and have examined a limited set of covariates, compared with the current study.

There was no association of vitamin D status with mortality or HIV disease progression in this cohort, unlike our previous studies among HIV-infected pregnant women $^{1320}$ or adults with HIV infection ${ }^{21} 22$ in Tanzania. The major difference is that in our earlier studies, ${ }^{13}{ }^{20}$ a large majority $(\sim 85 \%)$ of the participants had stage 1 or 
Table 4 Vitamin $\mathrm{D}$ status and T-cell counts (cells/ $\mu \mathrm{L})$ in patients with tuberculosis

\begin{tabular}{|c|c|c|c|c|c|c|c|c|c|c|c|c|}
\hline \multirow[b]{2}{*}{ Outcome } & \multicolumn{4}{|l|}{ CD4 T-cells } & \multicolumn{4}{|l|}{ CD8 T-cells } & \multicolumn{4}{|l|}{ CD3 T-cells } \\
\hline & $\begin{array}{l}\text { Adequate } \\
\text { vitamin D, } \\
\text { mean (SD)* }\end{array}$ & $\begin{array}{l}\text { Vitamin D } \\
\text { insufficiency, } \\
\text { mean difference } \\
(95 \% \mathrm{Cl}) \dagger\end{array}$ & $\begin{array}{l}\text { Vitamin D } \\
\text { insufficiency, } \\
\text { adjusted mean } \\
\text { difference }(95 \% \\
\text { Cl)‡ }\end{array}$ & $\begin{array}{l}p \\
\text { Value }\end{array}$ & $\begin{array}{l}\text { Adequate } \\
\text { vitamin } \mathrm{D}, \\
\text { mean (SD)* }\end{array}$ & $\begin{array}{l}\text { Vitamin D } \\
\text { insufficiency, } \\
\text { mean difference } \\
(95 \% \mathrm{Cl}) \dagger\end{array}$ & $\begin{array}{l}\text { Vitamin D } \\
\text { insufficiency, } \\
\text { adjusted mean } \\
\text { difference } \\
(95 \% \mathrm{Cl}) \ddagger\end{array}$ & $\begin{array}{l}\mathbf{p} \\
\text { Value }\end{array}$ & $\begin{array}{l}\text { Adequate } \\
\text { vitamin } \mathrm{D}, \\
\text { mean (SD)* }\end{array}$ & $\begin{array}{l}\text { Vitamin D } \\
\text { insufficiency, } \\
\text { mean difference } \\
(95 \% \mathrm{Cl}) \dagger\end{array}$ & $\begin{array}{l}\text { Vitamin D } \\
\text { insufficiency, } \\
\text { adjusted mean } \\
\text { difference }(95 \% \\
\mathrm{Cl}) \neq\end{array}$ & $\begin{array}{l}p \\
\text { Value }\end{array}$ \\
\hline \multicolumn{13}{|c|}{ Entire follow-up: patients with HIV infection } \\
\hline $\begin{array}{l}\text { Vitamin D } \\
\text { insufficiency } \\
\text { (<75 nmol/L) }\end{array}$ & $300(234)$ & $17(-23$ to 56$)$ & 21 ( -18 to 59$)$ & 0.29 & $902(457)$ & 88 (7 to 169 ) & 85 (4 to 165 ) & 0.04 & 1298 (635) & $101(-4$ to 206$)$ & $103(-5$ to 212$)$ & 0.06 \\
\hline $\begin{array}{l}\text { Vitamin D } \\
\text { deficient } \\
(<50 \mathrm{nmol} / \mathrm{L})\end{array}$ & $333(225)$ & $21(-34$ to 76$)$ & $30(-26$ to 86$)$ & 0.29 & $957(424)$ & 105 (-9 to 219$)$ & 114 (-6 to 234$)$ & 0.06 & $1392(595)$ & $104(-47$ to 255$)$ & 125 (-28 to 279$)$ & 0.11 \\
\hline $\begin{array}{l}\text { Continuous } \\
\text { vitamin } \mathrm{D} \\
\text { (per nmol/L) }\end{array}$ & & $0(-1$ to 1$)$ & $-1(-1$ to 0$)$ & 0.26 & & $-3(-5$ to -1$)$ & $-3(-5$ to -1$)$ & 0.004 & & $-3(-5$ to -1$)$ & $-3(-6$ to -1$)$ & 0.01 \\
\hline \multicolumn{13}{|c|}{ Entire follow-up: patients without HIV infection } \\
\hline $\begin{array}{l}\text { Vitamin D } \\
\text { insufficiency } \\
\text { (<75 nmol/L) }\end{array}$ & 771 (235) & $-2(-49$ to 45$)$ & $3(-45$ to 51$)$ & 0.91 & 508 (209) & $-25(-63$ to 14$)$ & $-22(-60$ to 17$)$ & 0.27 & $1351(400)$ & -37 ( -109 to 35$)$ & $-28(-99$ to 44$)$ & 0.45 \\
\hline $\begin{array}{l}\text { Vitamin D } \\
\text { deficient } \\
\text { (<50 nmol/L) }\end{array}$ & $781(241)$ & -34 (-99 to 30$)$ & $-34(-101$ to 32$)$ & 0.31 & $500(195)$ & -1 (-64 to 62$)$ & $3(-61$ to 67$)$ & 0.93 & 1354 (397) & $-33(-136$ to 71$)$ & $-28(-134$ to 79$)$ & 0.61 \\
\hline $\begin{array}{l}\text { Continuous } \\
\text { vitamin } D \\
\text { (per nmol/L) }\end{array}$ & & $0(-1$ to 1$)$ & $0(-1$ to 1$)$ & 0.97 & & $0(-1$ to 1$)$ & $0(-1$ to 1$)$ & 0.83 & & 0 (-1 to 2$)$ & 0 (-2 to 2$)$ & 0.90 \\
\hline \multicolumn{13}{|c|}{ First 8 months of follow-up: patients with HIV infection } \\
\hline $\begin{array}{l}\text { Vitamin D } \\
\text { insufficiency } \\
\text { (<75 nmol/L) }\end{array}$ & $316(237)$ & $54(8$ to 100$)$ & $58(13$ to 104$)$ & 0.01 & $868(470)$ & 132 (29 to 235$)$ & 119 (15 to 223$)$ & 0.02 & $1279(670)$ & 190 (42 to 337$)$ & 179 (28 to 331$)$ & 0.02 \\
\hline $\begin{array}{l}\text { Vitamin D } \\
\text { deficient } \\
(<50 \mathrm{nmol} / \mathrm{L})\end{array}$ & $372(264)$ & $36(-25$ to 97$)$ & $41(-20$ to 101$)$ & 0.19 & $963(471)$ & $63(-77$ to 203$)$ & 75 (-72 to 221$)$ & 0.32 & $1443(689)$ & $67(-125$ to 259$)$ & 101 (-93 to 295$)$ & 0.31 \\
\hline $\begin{array}{l}\text { Continuous } \\
\text { vitamin } D \\
\text { (per nmol/L) }\end{array}$ & & $-1(-2$ to 0$)$ & $-1(-2$ to 0$)$ & 0.01 & & $-4(-6$ to -1$)$ & $-4(-6$ to -1$)$ & 0.002 & & $-4(-7$ to -1$)$ & $-5(-8$ to -2$)$ & 0.003 \\
\hline \multicolumn{13}{|c|}{ First 8 months of follow-up: patients without HIV infection } \\
\hline $\begin{array}{l}\text { Vitamin D } \\
\text { insufficiency } \\
\text { (<75 nmol/L) }\end{array}$ & $724(243)$ & $1(-52$ to 53$)$ & $6(-47$ to 59$)$ & 0.82 & $461(232)$ & $-22(-63$ to 20$)$ & $-17(-57$ to 22$)$ & 0.39 & $1248(446)$ & $-38(-121$ to 46$)$ & $-27(-106$ to 52$)$ & 0.50 \\
\hline $\begin{array}{l}\text { Vitamin D } \\
\text { deficient } \\
\text { (<50 nmol/L) }\end{array}$ & $731(237)$ & $-7(-95$ to 80$)$ & $-7(-96$ to 81$)$ & 0.87 & 454 (209) & $4(-73$ to 81$)$ & $5(-71$ to 81$)$ & 0.90 & $1247(410)$ & $14(-124$ to 153$)$ & $17(-123$ to 156$)$ & 0.82 \\
\hline $\begin{array}{l}\text { Continuous } \\
\text { vitamin } D \\
\text { (per } \mathrm{nmol} / \mathrm{L} \text { ) }\end{array}$ & & $0(-2$ to 1$)$ & $0(-2$ to 1$)$ & 0.54 & & $0(-1$ to 1$)$ & $0(-1$ to 1$)$ & 0.73 & & $0(-2$ to 1$)$ & $0(-2$ to 1$)$ & 0.57 \\
\hline
\end{tabular}

(per $\mathrm{nmol} / \mathrm{L})$

* Data are the means (SD) of the average measurement during follow-up for each participant.

†Data are the mean difference between the low and the adequate vitamin D group. The mean differences, $95 \%$ Cls and corresponding $\mathrm{p}$ values were estimated from generalised estimating equations, after adjustment for baseline measurements, follow-up time and treatment (micronutrients vs placebo) group.

¥Multivariate analyses additionally adjusted for age, Karnofsky score and baseline haemoglobin. 
Table 5 Vitamin D status and nutritional parameters in patients with tuberculosis

\begin{tabular}{|c|c|c|c|c|c|c|c|c|c|c|c|c|}
\hline \multirow[b]{2}{*}{ Outcome } & \multicolumn{4}{|c|}{ Body mass index $\left(\mathrm{kg} / \mathrm{m}^{2}\right)$} & \multicolumn{4}{|c|}{ Albumin concentration ( $\mathrm{g} / \mathrm{dL}$ ) } & \multicolumn{4}{|c|}{ Haemoglobin concentration ( $\mathrm{g} / \mathrm{dL})$} \\
\hline & $\begin{array}{l}\text { Adequate } \\
\text { vitamin } D \text {, } \\
\text { mean }(S D)^{\star}\end{array}$ & $\begin{array}{l}\text { Vitamin D } \\
\text { insufficiency, } \\
\text { mean difference } \\
(95 \% \mathrm{Cl}) \dagger\end{array}$ & $\begin{array}{l}\text { Vitamin D } \\
\text { insufficiency, } \\
\text { adjusted mean } \\
\text { difference } \\
(95 \% \mathrm{Cl}) \ddagger\end{array}$ & $\begin{array}{l}p \\
\text { Value }\end{array}$ & $\begin{array}{l}\text { Adequate } \\
\text { vitamin } \mathrm{D} \text {, } \\
\text { mean (SD) }\end{array}$ & $\begin{array}{l}\text { Vitamin D } \\
\text { insufficiency, } \\
\text { mean difference } \\
(95 \% \mathrm{Cl}) \dagger\end{array}$ & $\begin{array}{l}\text { Vitamin D } \\
\text { insufficiency, } \\
\text { adjusted mean } \\
\text { difference } \\
(95 \% \mathrm{Cl}) \neq\end{array}$ & $\begin{array}{l}p \\
\text { Value }\end{array}$ & $\begin{array}{l}\text { Adequate } \\
\text { vitamin } \mathrm{D} \text {, } \\
\text { mean }(\mathrm{SD})^{\star}\end{array}$ & $\begin{array}{l}\text { Vitamin D } \\
\text { insufficiency, } \\
\text { mean difference } \\
(95 \% \mathrm{Cl}) \dagger\end{array}$ & $\begin{array}{l}\text { Vitamin D } \\
\text { insufficiency, } \\
\text { adjusted mean } \\
\text { difference } \\
(95 \% \mathrm{Cl}) \neq\end{array}$ & $\begin{array}{l}p \\
\text { Value }\end{array}$ \\
\hline \multicolumn{13}{|c|}{ Entire follow-up: all patients } \\
\hline $\begin{array}{l}\text { Vitamin D } \\
\text { insufficiency } \\
(<75 \mathrm{nmol} / \mathrm{L})\end{array}$ & $21.20(2.80)$ & $\begin{array}{l}-0.06(-0.30 \text { to } \\
0.17)\end{array}$ & $\begin{array}{l}-0.08 \text { ( }-0.30 \text { to } \\
0.14)\end{array}$ & 0.46 & $3.42(0.74)$ & $\begin{array}{l}-0.05(-0.14 \text { to } \\
0.04)\end{array}$ & $\begin{array}{l}0.00(-0.08 \text { to } \\
0.08)\end{array}$ & 0.97 & $12.65(1.80)$ & $\begin{array}{l}-0.16(-0.40 \text { to } \\
0.08)\end{array}$ & $\begin{array}{l}-0.18(-0.41 \text { to } \\
0.05)\end{array}$ & 0.12 \\
\hline $\begin{array}{l}\text { Vitamin } D \\
\text { deficient } \\
(<50 \mathrm{nmol} / \mathrm{L})\end{array}$ & $21.23(3.00)$ & $\begin{array}{l}-0.16(-0.46 \text { to } \\
0.14)\end{array}$ & $\begin{array}{l}-0.14(-0.44 \text { to } \\
0.15)\end{array}$ & 0.34 & $3.42(0.72)$ & $\begin{array}{l}-0.05(-0.17 \text { to } \\
0.07)\end{array}$ & $\begin{array}{l}0.02(-0.08 \text { to } \\
0.13)\end{array}$ & 0.65 & $12.42(1.87)$ & $\begin{array}{l}0.15(-0.16 \text { to } \\
0.45)\end{array}$ & $\begin{array}{l}0.17(-0.11 \text { to } \\
0.45)\end{array}$ & 0.24 \\
\hline $\begin{array}{l}\text { Continuous } \\
\text { vitamin } D \\
\text { (per nmol/L) }\end{array}$ & & $0.00(0.00$ to 0.01$)$ & $0.00(0.00$ to 0.01$)$ & 0.30 & & $\begin{array}{l}0.002 \text { (0.00 to } \\
0.004)\end{array}$ & $\begin{array}{l}0.000(-0.002 \text { to } \\
0.002)\end{array}$ & 0.90 & & $\begin{array}{l}0.00(-0.01 \text { to } \\
0.01)\end{array}$ & $0.00(0.00$ to 0.01$)$ & 0.85 \\
\hline \multicolumn{13}{|c|}{ First 8 months of follow-up: all patients } \\
\hline $\begin{array}{l}\text { Vitamin D } \\
\text { insufficiency } \\
\text { (<75 nmol/L) }\end{array}$ & $20.96(2.73)$ & $\begin{array}{l}-0.20(-0.40 \text { to } \\
-0.01)\end{array}$ & $\begin{array}{l}-0.21(-0.39 \text { to } \\
-0.02)\end{array}$ & 0.03 & $3.42(1.09)$ & $\begin{array}{l}-0.01(-0.18 \text { to } \\
0.16)\end{array}$ & $\begin{array}{l}0.04(-0.13 \text { to } \\
0.21)\end{array}$ & 0.65 & $12.12(1.85)$ & $\begin{array}{l}-0.01(-0.28 \text { to } \\
0.26)\end{array}$ & $\begin{array}{l}-0.04(-0.31 \text { to } \\
0.23)\end{array}$ & 0.78 \\
\hline $\begin{array}{l}\text { Vitamin D } \\
\text { deficient } \\
(<50 \mathrm{nmol} / \mathrm{L})\end{array}$ & $20.85(2.84)$ & $\begin{array}{l}0.00(-0.25 \text { to } \\
0.25)\end{array}$ & $\begin{array}{l}0.04(-0.21 \text { to } \\
0.29)\end{array}$ & 0.78 & $3.41(1.08)$ & $\begin{array}{l}-0.11(-0.32 \text { to } \\
0.10)\end{array}$ & $\begin{array}{l}-0.05(-0.27 \text { to } \\
0.17)\end{array}$ & 0.64 & $11.92(1.99)$ & $\begin{array}{l}0.16(-0.18 \text { to } \\
0.50)\end{array}$ & $\begin{array}{l}0.21(-0.10 \text { to } \\
0.53)\end{array}$ & 0.19 \\
\hline $\begin{array}{l}\text { Continuous vit } \\
\mathrm{nmol} / \mathrm{L})\end{array}$ & itamin D (per & 0.00 (0.00 to 0.01$)$ & 0.00 (0.00 to 0.01$)$ & 0.38 & & $\begin{array}{l}0.000(-0.003 \text { to } \\
0.005)\end{array}$ & $\begin{array}{l}0.000(-0.004 \text { to } \\
0.004)\end{array}$ & 0.87 & & $\begin{array}{l}0.00(-0.01 \text { to } \\
0.00)\end{array}$ & $\begin{array}{l}0.00(-0.01 \text { to } \\
0.00)\end{array}$ & 0.57 \\
\hline
\end{tabular}

${ }^{*}$ Data are the means (SD) of the average measurement during follow-up for each participant.

† Data are the mean difference between the low and the adequate vitamin D group. The mean differences, $95 \%$ Cls and corresponding $p$ values were estimated from generalised estimating equations, after adjustment for baseline measurements, follow-up time and treatment (micronutrients vs placebo) group.

¥Multivariate analyses additionally adjusted for age, Karnofsky score, baseline haemoglobin, viral load, CD4 T cell count and HIV status; HIV status removed from the model where the results are stratified by HIV status. Viral load also removed from the model in HIV-uninfected individuals. 
asymptomatic HIV disease, whereas in this study, most of the individuals were already at stage 3 disease.

The association of vitamin D insufficiency with TB recurrence/relapse, primarily driven by the HIV-uninfected subset, is a novel finding in a longitudinal study and has important implications. Vitamin D deficiency has been linked to TB in several studies-a hypothesis perhaps initially generated by the observed seasonality of TB. In vitro and animal studies indicate that 1,25-dihydroxyvitamin $\mathrm{D}_{3}$, the most active form of vitamin $\mathrm{D}$, may not only increase mycobacterial killing by macrophages but also limits host damage by decreasing the $\gamma$-interferon production. ${ }^{23-28}$ In perhaps the strongest evidence to date for a role of vitamin $\mathrm{D}$ in $\mathrm{TB}$, a study by Liu $e t a t^{29}$ found that the antimycobacterial response in humans is dependent on an adequate availability of vitamin $\mathrm{D}$.

A few randomised trials of vitamin D supplementation in patients with TB have been conducted in the past few years. ${ }^{4} 530$ In a randomised trial that was conducted among 365 patients with TB in Guinea-Bissau starting antituberculosis treatment, overall mortality was $15 \%$ (54 of 365) at 1 year of follow-up and similar in both arms. ${ }^{5}$ Martineau et a ${ }^{4}$ did not find a difference in median time to sputum culture conversion with vitamin D supplementation of $2.5 \mathrm{mg}$ vitamin $\mathrm{D}_{3}$ at enrolment, 14,28 and 42 days after starting TB treatment in 126 adults with sputum smear-positive PTB. A recent report by Coussens et $a l^{30}$ from a subset of the 126 adults included in the trial above stated that median time to sputum smear conversion in the intervention arm was significantly shorter than in the control arm (23 vs 36 days; $\mathrm{p}=0.04$ ). The lack of effect and concordance in most of these trials is probably due to the dose and dosing interval used. It is worth noting however, that large intermittent doses of vitamin $\mathrm{D}$ may result in supraphysiological concentrations in some cases, which may be more harmful than helpful in their effects on the immune system. ${ }^{31}$

Vitamin D insufficiency also was associated with T-cell subset counts only among the patients with HIV infection in this cohort. We can only speculate as to the reasons for the significantly higher increase in CD4 T-cells observed in patients with vitamin $\mathrm{D}$ insufficiency at baseline. One potential explanation is that patients with HIV infection with vitamin D insufficiency may experience more uncontrolled immune reconstitution, leading to a greater increase in $\mathrm{CD} 4 \mathrm{~T}$-cell counts, on treatment of TB, compared with patients with adequate vitamin D status. This may also explain why this relationship is observed only in the first 8 months of follow-up and not subsequently.

The results for CD8 and CD3 T-cells are consistent with our previous studies among women with HIV infection in Tanzania. ${ }^{13}{ }^{14}$ This could suggest a possible role of vitamin $\mathrm{D}$ in inflammation. Although, the conventional role of CD8 cells is as cytotoxic cells, they also are effector cells in inflammation. ${ }^{32}$ The involvement of vitamin $\mathrm{D}$ in modulating CD8 cells is also indicated by the fact that CD8 cells express the highest concentration of vitamin D receptor of the immune cells. ${ }^{33}$ Other studies also have found that vitamin $\mathrm{D}$ suppresses antigen-stimulated proinflammatory cytokine responses, which may help speed up the resolution of inflammatory responses that can lead to increased risk of mortality among patients with $\mathrm{TB} .{ }^{30}$

TB, once known as 'consumption', is associated with significant wasting and weight loss. The observation that better vitamin D status among patients without HIV infection is associated with a greater increase in BMI during follow-up is likely related to decreased risk of relapse among these patients, as well as improvement in quality of life through mechanisms such as better metabolism that were not directly assessed in this study.

The major strengths of this study include a large number of participants, more than half of whom were HIV-infected, comprehensive assessment of clinical, immunological, sociodemographic and nutritional parameters, and a long duration of follow-up. On the other hand, the major limitation is the possibility of reverse causation and residual confounding. We have attempted to minimise this through rigorous analyses and adjusting for several potential confounders, including haemoglobin concentrations, HIV status, viral load, CD4 T-cells and Karnofsky score, in most analyses. The study results are generalisable to most settings with a high TB burden and widely prevalent vitamin $\mathrm{D}$ insufficiency.

In summary, our study results indicate that adequate vitamin $\mathrm{D}$ status is associated with better clinical and nutritional parameters during follow-up in a cohort of patients with TB in Tanzania. While randomised trials of vitamin $\mathrm{D}$ supplementation among patients with $\mathrm{TB}$ are urgently warranted, it is also imperative to conduct dose - response studies to determine ideal dose and duration for the supplement.

\section{Author affiliations}

${ }^{1}$ Division of Nutritional Sciences, Cornell University, Ithaca, New York, USA ${ }^{2}$ Department of Internal Medicine, Muhimbili University of Health and Allied Sciences, Dar es Salaam, United Republic of Tanzania

${ }^{3}$ Department of Biostatistics, Harvard School of Public Health, Boston, Massachusetts, USA

${ }^{4}$ Department of Microbiology and Immunology, Muhimbili University of Health and Allied Sciences, Dar es Salaam, United Republic of Tanzania

${ }^{5}$ Diagnostics and Laboratory Technology Team, World Health Organization, Geneva, Switzerland

${ }^{6}$ Department of Epidemiology, University of Michigan School of Public Health, Ann Arbor, Michigan, USA

${ }^{7}$ Departments of Global Health and Population, Nutrition, and Epidemiology, Harvard School of Public Health, Boston, Massachusetts, USA

Acknowledgements The authors would like to thank the patients, whose participation made this study possible. We are grateful to the study coordinator, Dorothy Mallya, and to the study physicians, research nurses, and laboratory and administrative staff at Muhimbili University of Health and Allied Sciences in Dar es Salaam, Tanzania, for their contributions to the project.

Contributors SM wrote the first draft of the manuscript and analysed and interpreted the data; FMM, RJB, SA, WU, EV and WWF were investigators of the parent trial and contributed to field activities and oversight; RJB also helped with the analysis and interpretation of the data; all authors participated 
in study design and contributed to the final manuscript. All authors have also read and approved the final manuscript.

Funding National Institute of Allergy and Infectious Diseases, National Institutes of Health (grant U01AI045441 to support the study).

\section{Competing interests None.}

Ethics approval The institutional review boards of the Muhimbili University of Health and Allied Sciences, the Tanzanian National AIDS Control Program and the Harvard School of Public Health approved the study protocol.

Provenance and peer review Not commissioned; externally peer reviewed.

Data sharing statement No additional data are available.

Open Access This is an Open Access article distributed in accordance with the Creative Commons Attribution Non Commercial (CC BY-NC 3.0) license, which permits others to distribute, remix, adapt, build upon this work noncommercially, and license their derivative works on different terms, provided the original work is properly cited and the use is non-commercial. See: http:// creativecommons.org/licenses/by-nc/3.0/

\section{REFERENCES}

1. WHO. Global tuberculosis control. Geneva: World Health Organization, 2011.

2. Chaisson RE, Martinson NA. Tuberculosis in Africa-combating an HIV-driven crisis. N Engl J Med 2008;358:1089-92.

3. Martineau AR, Nhamoyebonde S, Oni T, et al. Reciprocal seasonal variation in vitamin $D$ status and tuberculosis notifications in Cape Town, South Africa. Proc Natl Acad Sci USA 2011;108:19013-17.

4. Martineau AR, Timms PM, Bothamley GH, et al. High-dose vitamin $\mathrm{D}(3)$ during intensive-phase antimicrobial treatment of pulmonary tuberculosis: a double-blind randomised controlled trial. Lancet 2011;377:242-50

5. Wejse C, Gomes VF, Rabna P, et al. Vitamin D as supplementary treatment for tuberculosis: a double-blind, randomized, placebo-controlled trial. Am J Respir Crit Care Med 2009;179:843-50.

6. Villamor E, Mugusi F, Urassa W, et al. A Trial of the effect of micronutrient supplementation on treatment outcome, T cell counts, morbidity, and mortality in adults with pulmonary tuberculosis. $J$ Infect Dis 2008;197:1499-505

7. Karnofsky DA, Abelmann WH, Craver LF, et al. The use of nitrogen mustards in the palliative treatment of cancer. Cancer 1948;1:634-56.

8. Fawzi WW, Msamanga GI, Spiegelman D, et al. A randomized trial of multivitamin supplements and HIV disease progression and mortality. N Engl J Med 2004;351:23-32.

9. Baum M, Cassetti L, Bonvehi $P$, et al. Inadequate dietary intake and altered nutrition status in early HIV-1 infection. Nutrition 1994;10:16-20.

10. Lohman TG, Roche AF, Martorell R. Anthropometric standardization reference manual. Champaign, IL: Human Kinetics Books, 1988.

11. WHO. Interim proposal for a WHO staging system for HIV infection and disease. Wkly Epidemiol Rec 1990;65:221-4.

12. Friis $\mathrm{H}$, Range N, Pedersen ML, et al. Hypovitaminosis D is common among pulmonary tuberculosis patients in Tanzania but is not explained by the acute phase response. J Nutr 2008;138:2474-80.

13. Mehta S, Giovannucci E, Mugusi FM, et al. Vitamin D status of HIV-infected women and its association with HIV disease progression, anemia, and mortality. PLOS ONE 2010;5:e8770.
14. Mehta S, Spiegelman D, Aboud S, et al. Lipid-soluble vitamins A, D, and $\mathrm{E}$ in HIV-infected pregnant women in Tanzania. Eur J Clin Nutr 2010;64:808-17.

15. Davies PD, Church HA, Bovornkitti S, et al. Altered vitamin D homeostasis in tuberculosis. Intern Med (Thailand) 1988;4:45-7.

16. Norman AW. Nutritional aspects of vitamin D. http://vitamind.ucr.edu/ nutri.html (accessed 9 Oct 2006. 1999). http://vitamind.ucr.edu/nutri. html (accessed 9 Oct 2006).

17. Utiger RD. The need for more vitamin D. N Engl J Med 1998;338:828-9.

18. Holick MF. High prevalence of vitamin D inadequacy and implications for health. Mayo Clin Proc 2006;81:353-73.

19. Greenland S. Modeling and variable selection in epidemiologic analysis. Am J Public Health 1989;79:340-9.

20. Mehta S, Mugusi FM, Spiegelman D, et al. Vitamin D status and its association with morbidity including wasting and opportunistic illnesses in HIV-infected women in Tanzania. AIDS Patient Care STDS 2011;25:579-85.

21. Sudfeld CR, Giovannucci EL, Isanaka S, et al. Vitamin D status and incidence of pulmonary tuberculosis, opportunistic infections, and wasting among HIV-infected Tanzanian adults initiating antiretroviral therapy. J Infect dis 2013;207:378-85.

22. Sudfeld CR, Wang M, Aboud S, et al. Vitamin D and HIV progression among Tanzanian adults initiating antiretroviral therapy. PLOS ONE 2012;7:e40036.

23. Thoma-Uszynski S, Stenger S, Takeuchi O, et al. Induction of direct antimicrobial activity through mammalian toll-like receptors. Science 2001;291:1544-7

24. Waters WR, Palmer MV, Nonnecke BJ, et al. Mycobacterium bovis infection of vitamin D-deficient NOS2-/- mice. Microb Pathog 2004;36:11-17

25. Waters WR, Nonnecke BJ, Foote MR, et al. Mycobacterium bovis bacille Calmette-Guerin vaccination of cattle: activation of bovine CD4+ and gamma delta TCR + cells and modulation by 1,25-dihydroxyvitamin D3. Tuberculosis 2003;83:287-97.

26. Waters WR, Nonnecke BJ, Rahner TE, et al. Modulation of Mycobacterium bovis-specific responses of bovine peripheral blood mononuclear cells by 1,25-dihydroxyvitamin D(3). Clin Diagn Lab Immunol 2001;8:1204-12.

27. Kawakami K, Teruya K, Tohyama M, et al. [A therapeutic trial of experimental tuberculosis with gamma-interferon in an immunocompromised mouse model]. Kekkaku 1994;69:607-13.

28. McMurray DN, Bartow RA, Mintzer CL, et al. Micronutrient status and immune function in tuberculosis. Ann NY Acad Sci 1990;587:59-69.

29. Liu PT, Stenger S, Li H, et al. Toll-like receptor triggering of a vitamin D-mediated human antimicrobial response. Science 2006;311:1770-3.

30. Coussens AK, Wilkinson RJ, Hanifa $Y$, et al. Vitamin D accelerates resolution of inflammatory responses during tuberculosis treatment. Proc Natl Acad Sci USA 2012;109:15449-54.

31. Martineau AR. Bolus-dose vitamin D and prevention of childhood pneumonia. Lancet 2012;379:1373-5.

32. Babbe $\mathrm{H}$, Roers A, Waisman A, et al. Clonal expansions of CD8(+) $T$ cells dominate the $T$ cell infiltrate in active multiple sclerosis lesions as shown by micromanipulation and single cell polymerase chain reaction. J Exp Med 2000;192:393-404.

33. Veldman CM, Cantorna MT, DeLuca HF. Expression of 1,25-dihydroxyvitamin D(3) receptor in the immune system. Arch Biochem Biophys 2000;374:334-8. 